\title{
STRATEGI PENANGGULANGAN KEMISKINAN MELALUI PENGEMBANGAN PERTANIAN DI KABUPATEN BOGOR, STUDI KASUS DI KECAMATAN PEMIJAHAN DAN LEUWILIANG
}

\author{
Strategies in Alleviating Poverty through Agricultural Development in Bogor Regency (Case Study in \\ Pamijahan and Leuwiliang Subdistrict)
}

\author{
Jenal Abidin 1, Rina Octaviani ${ }^{2}$, dan Fredian Tonny Nasdian ${ }^{3}$ \\ 1 Staff Pengajar Direktorat Program Diploma IPB. E-mail: mpdipb@hotmail.com \\ 2 Staff Pengajar Departemen Ilmu Ekonomi. Fakultas Ekonomi dan Manajemen IPB. E- \\ mail:oktavianirina1@gmail.com
}

3 Staff Pengajar Departemen Sains dan Komunikasi Pengembangan Masyarakat. Fakultas Ekologi ManusiaIPB. E-mail: frediantonny@apps.ipb.ac.id

\begin{abstract}
Bogor Regency has big potential in agricultural resources with population about 4,2 million of which 20,4 percent work as farmers. Yet, the number of people living under poverty is around 1,1 million. Therefore research to find strategy in alleviating poverty is important. The main objective of this research is to formulate stategies in alleviating poverty by agricultural development in Bogor Regency. Moreover, specific purposes are: 1) Identifying the characteristic and the buying power of people in Bogor Regency; 2) Analyzing the correlation between the poverty rate and the household characteristic in Bogor Regency; 3) Analyzing potential agricultural commodities in Bogor Regency and 4) Evaluating Government Policy in alleviating poverty at Bogor Regency. Methods used in this research were Quantitative Descriptive Analysis, Correlation Analysis, and LQ. The SWOT and QSPM Analysis were also used to formulate strategies. Nine strategies, which are alternative strategies to be applied by the government of Bogor Regency, are designed to alleviate poverty in Bogor Regency through Agricultural development. Poverty allevieting in Bogor Regency should be focused on three strategies, those are: 1) Increase of human resource quality of farmers; 2) Development of potential commodities, i.e. wetland rice, sweet potato, siam orange, and mangosteen; and 3) Development of agricultural infrastructure and facility.
\end{abstract}

Keywords: Strategies, Bogor Regency, Poverty, Policy, Agriculture

\begin{abstract}
ABSTRAK
Kabupaten Bogor memiliki potensi sumberdaya alam pertanian untuk dikembangkan yang didukung oleh populasi yang mencapai 4,2 juta jiwa, dimana 20,4 persen dari jumlah tersebut bermata pencaharian sebagai petani. Namun kenyataannya, penduduk miskin mencapai lebih dari 1,1 juta jiwa. Untuk itu, penelitian terkait perancangan strategi penanggulangan kemiskinan perlu dilakukan. Tujuan umum penelitian ini adalah untuk merumuskan strategi dan program penanggulangan kemiskinan melalui pengembangan pertanian di Kabupaten Bogor dengan tujuan khusus antara lain: 1) Mengidentifikasi karakteristik dan kemampuan daya beli masyarakat miskin di Kabupaten Bogor; 2) Menganalisis hubungan antara tingkat kemiskinan dengan beberapa karakteristik rumahtangga miskin di Kabupaten Bogor; 3) Menganalisis komoditas pertanian unggulan di Kabupaten Bogor; dan 4) Mengevaluasi kebijakan pemerintah dalam penanggulangan kemiskinan di Kabupaten Bogor. Metode yang digunakan yaitu analisis deskriptif kuantitatif, analisis korelasi, dan analisis LQ. Metode SWOT dan QSPM digunakan untuk merumuskan strategi alternatif. Hasil kajian menetapkan 9 strategi penanggulangan kemiskinan melalui pengembangan pertanian di Kabupaten Bogor, yang merupakan alternatif strategi yang dapat dijalankan ke depan oleh pemerintah daerah Kabupaten Bogor. Penanggulangan kemiskinan di Kabupaten Bogor harus difokuskan kepada tiga strategi yaitu: 1) Peningkatan kualitas SDM petani; 2) Pengembangan komoditas unggulan padi sawah, ubi jalar, jeruk siam dan manggis; dan 3) Peningkatan sarana dan prasarana pertanian.
\end{abstract}




\section{PENDAHULUAN}

\section{Latar Belakang}

\section{Kabupaten Bogor merupakan} bagian dari Propinsi Jawa Barat yang memiliki berbagai potensi yang belum dikembangkan secara optimal. Kabupaten Bogor dalam rangka mengembangkan potensi tersebut, membutuhkan peran dari pemerintah dan masyarakat untuk mengelola dan mengembangkan potensi yang dimiliki. Salah satu potensi yang dimiliki Kabupaten Bogor adalah sumberdaya alam pertanian berupa lahan yang masih luas yang dapat menjadi basis perekonomian daerah sebagai upaya penanggulangan kemiskinan.

Potensi sumberdaya alam di Kabupaten Bogor yang berupa luas lahan pertanian dari tahun ke tahun masih terluas jika dibandingkan dengan sektor lainnya walaupun mengalami fluktuasi. Bertambahnya luas lahan pertanian pada tahun 2007 terjadi karena reboisasi dan pembukaan hutan menjadi lahan pertanian, pada tahun 2008 terjadi alih fungsi lahan menjadi pemukiman sehingga menyebabkan luas lahan pertanian berkurang (Tabel 1).

Tabel 1. Potensi Sumberdaya Alam di Kabupaten Bogor (ha)

\begin{tabular}{lccc}
\hline \multicolumn{1}{c}{ Potensi } & 2006 & 2007 & 2008 \\
\hline Pertanian & 149.748 & 180.898 & 175.320 \\
Perkebunan & 24.063 & 22.126 & 23.577 \\
Kehutanan & 108.033 & 79.380 & 79.436 \\
Lainnya & 28.189 & 27.629 & 31.700 \\
\hline \multicolumn{2}{c}{ Sumber: }
\end{tabular}

Potensi lain disamping luas lahan pertanian, Kabupaten Bogor juga memiliki luas wilayah dan jumlah penduduk yang besar. Luas wilayah yang mencapai 2.301, 95 kilometer persegi yang terdiri dari 40 kecamatan dan 428 desa dengan jumlah penduduk yang besarnya mencapai 4.215.585 jiwa pada tahun 2006 (Bappeda, 2006) tampaknya tidak mampu mencerminkan tingkat kesejahteraan di Kabupaten Bogor. Besarnya luas wilayah dan jumlah penduduk di Kabupaten Bogor malah menjadi permasalahan tersendiri dengan banyaknya masyarakat miskin. Jumlah penduduk miskin di Kabupaten Bogor mencapai 1.026 .789 jiwa $(24,15 \%)$, artinya setiap 100 orang penduduk terdapat 24 orang miskin. Jika dilihat dari berbagai potensi yang dimiliki seperti diatas, seharusnya kemiskinan di Kabupaten Bogor dapat ditanggulangi dengan baik oleh pemerintah, namun faktanya kemiskinan masih tetap menjadi permasalahan yang belum tuntas diselesaikan. Oleh karenanya, perlu dilakukan sebuah kajian mengenai strategi penanggulangan kemiskinan melalui pengembangan pertanian di Kabupaten Bogor.

\section{Perumusan Masalah}

Salah satu program pemerintah dalam upaya penanggulangan kemiskinan di Kabupaten Bogor adalah program revitalisasi pertanian pada 40 kecamatan, diantaranya Kecamatan Pamijahan dan Kecamatan Leuwiliang. Beberapa langkah strategis sebagai upaya penanggulangan kemiskinan telah dilaksanakan antara lain: Raskin, Bantuan Langsung Tunai (BLT), Program Usaha Agribisnis Perdesaan (PUAP), Gerakan Masyarakat Mandiri (GMM), Lembaga Usaha Ekonomi Perdesaan (LUEP), Program Ketahanan Pangan (PKP) dan Kelompok Usaha Bersama Ekonomi (KUBE) (Bappeda, 2006).

Namun, rendahnya pendapatan penduduk miskin semakin menambah 
$\begin{array}{lcc}\text { permasalahan } & \text { kemiskinan } & \text { sehingga } \\ \text { menyebabkan } & \text { lemahnya } & \text { motivasi }\end{array}$

masyarakat berperan serta pada program pembangunan ekonomi perdesaan. Untuk itu, perlu dikaji karakteristik masyarakat miskin dan kemampuan daya beli masyarakat miskin di Kabupaten Bogor. Dalam upaya mengatasi kemiskinan di perdesaan, diperlukan pemahaman mengenai karakteristik rumahtangga miskin (RTM), penyebab dan bagaimana hubungannya dengan tingkat kemiskinan, sehingga menjadikan masyarakat menjadi miskin. Karena itu perlu dilakukan suatu kajian dalam rangka menggali informasi mengenai hubungan antara tingkat kemiskinan dengan beberapa karakteristik (RTM) di Kabupaten Bogor.

Pemerintah perlu mengembangkan ragam komoditas menjadi usaha komoditas unggulan. Pengembangan usaha komoditas tersebut dikelola terintegrasi dan berkelanjutan sehingga dapat dijadikan dasar petimbangan bagi pemerintah daerah dalam mengambil kebijakan sebagai upaya penanggulangan kemiskinan yang sesuai dengan kondisi sosial ekonomi masyarakat. Untuk itu perlu diketahui informasi terkait komoditas unggulan pertanian yang dapat dikembangkan guna meningkatkan pendapatan rumahtangga miskin tersebut.

Penanggulangan kemiskinan memerlukan pendekatan yang integral baik secara sosial, ekonomi dan budaya. Bentuk program yang dilakukan oleh pemerintah belum mencerminkan aspirasi masyarakat miskin seutuhnya, lemahnya pengendalian pelaksanaan program dan mekanisme pelaksanaan kurang transparan, sehingga menyebabkan program tidak efektif dan efisien, sehingga diperlukan evaluasi program penanggulangan kemiskinan yang dilaksanakan oleh pemerintah di Kabupaten Bogor.

\section{Tujuan Penelitian}

Tujuan umum dari kajian ini adalah merumuskan strategi penanggulangan kemiskinan melalui pengembangan pertanian di Kabupaten Bogor. Sedangkan tujuan spesifik dari kajian ini dimaksudkan untuk:

1. Mengidentifikasi karakteristik dan kemampuan daya beli masyarakat miskin di Kabupaten Bogor

2. Menganalisis hubungan antara tingkat kemiskinan dengan karakteristik rumahtangga miskin di Kabupaten Bogor

3. Menganalisis komoditas pertanian unggulan di Kabupaten Bogor untuk penanggulangan kemiskinan

4. Mengevaluasi kebijakan pemerintah dalam penanggulangan kemiskinan

\section{TINJAUAN PUSTAKA}

\section{Konsep dan Indikator Kemiskinan}

Kemiskinan merupakan permasalahan pembangunan yang dihadapi oleh setiap daerah di Indonesia, khususnya pada negara-negara yang sedang berkembang. Kemiskinan sangat berkaitan erat dengan faktor-faktor tertentu misalnya pendapatan, pendidikan, kesehatan, akses terhadap barang dan jasa, dan kondisi lingkungan.

Kemiskinan memiliki konsep yang sangat beragam, mulai dari sekedar ketidakmampuan memenuhi kebutuhan konsumsi dasar dan memperbaiki keadaan, kurangnya kesempatan berusaha, hingga pengertian yang lebih luas yang memasukkan aspek sosial dan moral. Tetapi pada umumnya, ketika orang berbicara tentang kemiskinan, yang dimaksud adalah kemiskinan material. Berdasarkan pengertian ini, maka seseorang masuk dalam kategori miskin apabila tidak mampu memenuhi standar minimum kebutuhan pokok untuk dapat hidup secara layak hal inilah yang sering 
disebut dengan kemiskinan konsumsi. Definisi ini sangat bermanfaat untuk mempermudah membuat indikator orang miskin, tetapi definisi ini sangat kurang memadai karena 1) Tidak cukup untuk memahami realitas kemiskinan; 2) Dapat menjerumuskan kepada kesimpulan yang salah bahwa menanggulangi kemiskinan cukup hanya dengan menyediakan bahan makanan yang memadai; 3) Tidak bermanfaat bagi pengambil keputusan ketika harus merumuskan kebijakan lintas sektor, bahkan bisa kontra produktif.

Ritonga (2003) menyatakan bahwa miskin adalah kondisi kehidupan masyarakat yang sangat serba kekurangan yang dialami seseorang sehingga ia tidak mampu memenuhi kebutuhan dasarnya. Selanjutnya, BAPPENAS (2004) mendefinisikan kemiskinan sebagai kondisi dimana seseorang atau sekelompok orang laki-laki dan perempuan tidak mampu memenuhi hak-hak dasarnya untuk mempertahankan dan mengembangkan kehidupan yang bermartabat. Hak-hak dasar masyarakat desa antara lain, terpenuhinya kebutuhan pangan, kesehatan, pendidikan, pekerjaan, perumahan, air bersih, pertanahan, sumberdaya alam dan lingkungan hidup, rasa aman dari perlakuan atau ancaman tindak kekerasan dan hak untuk berpartisipasi dalam kehidupan sosial politik, baik bagi perempuan maupun lakilaki. Untuk mewujudkan hak-hak dasar masyarakat miskin ini, BAPPENAS menggunakan beberapa pendekatan utama antara lain: pendekatan kebutuhan dasar (basic needs approach), pendekatan pendapatan (income approach), pendekatan kemampuan dasar (human capability approach) dan pendekatan objective and subjective.

$$
\text { Badan Pusat Statistik }
$$

mendefinisikan kemiskinan sebagai suatu kondisi dimana pendapatan seseorang berada dibawah garis kemiskinan, yaitu besarnya rupiah yang dikeluarkan untuk konsumsi pangan dan non pangan (sandang, perumahan, kesehatan, pendidikan, angkutan dan bahan bakar). Berdasarkan indikator internasional seperti terdefinisi miskin dalam kategori MDGs (Millenium Development Goals) adalah warga miskin yang berpendapatan dibawah satu dolar AS setiap harinya. Kemudian Asian Development menggunakan dasar garis kemiskinan yang ditetapkan oleh Bank Dunia sebesar US\$ 2 per kapita per hari, setelah dikonversi kedalam rupiah menjadi sekitar Rp 540.000 per bulan.

Sajogyo (1987), mengungkapkan kemiskinan merupakan suatu tingkat kehidupan yang berada dibawah standar kebutuhan hidup minimum yang ditetapkan berdasarkan atas kebutuhan pokok pangan yang membuat orang cukup bekerja dan hidup sehat didasarkan pada kebutuhan beras dan kebutuhan gizi. Sajogyo dalam menentukan garis kemiskinan menggunakan ekuivalen konsumsi beras per kapita. Konsumsi beras untuk perkotaan dan perdesaan masingmasing ditentukan sebesar $360 \mathrm{~kg}$ dan 240 $\mathrm{kg}$ per kapita per tahun. Beberapa konsep dasar mengenai kemiskinan diatas merupakan konsep yang berkembang di masyarakat, masih banyak konsep lain mengenai kemiskinan yang dapat kita pelajari sebagai definisi kemiskinan, tetapi pada intinya hampir semua sumber sepakat bahwa kemiskinan pada dasarnya adalah ketidakmampuan seseorang untuk memenuhi kebutuhan dasarnya dalam kehidupan sehari-hari.

Ditinjau dari penyebabnya, kemiskinan dibedakan menjadi kemiskinan struktural yang disebabkan oleh faktor eksternal yang berada di luar jangkauan individu serta kemiskinan kultural yang berasal dari dalam diri seseorang atau lingkungannya sebagai akibat nilai-nilai dan kebudayaan yang dianut sekelompok masyarakat (Sumodiningrat, 1999).

Kemiskinan dicirikan oleh tiga hal, yaitu rendahnya penguasaan aset, rendahnya kemampuan masyarakat meningkatkan kepemilikan aset, serta rendahnya kemampuan dalam mengelola aset (Hendrakusumaatmaja, 2002). 
Menurut BKKBN indikator kemiskinan disebut sebagai keluarga pra sejahtera yang dikeluarkan secara nasional adalah seluruh anggota keluarga yang mampu untuk makan dua kali sehari atau lebih, seluruh anggota keluarga memiliki pakaian yang berbeda untuk di rumah, bekerja, sekolah dan bepergian, bagian terluas dari lantai rumah bukan dari tanah dan apabila anak atau anggota keluarga lainnya sakit dapat di bawa ke sarana/petugas kesehatan, kemudian pasangan usia subur (PUS) ingin berkeluarga berencana (KB) dibawa ke sarana atau petugas kesehatan dan diberi obat dengan cara KB Modern.

Badan Pusat Statistik (2004) telah menetapkan empat belas kriteria keluarga miskin yang salah satunya memiliki sumber pendapatan di bawah Rp 600.000 per bulan. Kemiskinan adalah suatu situasi atau kondisi yang dialami oleh seseorang atau kelompok orang yang tidak mampu menyelenggarakan hidupnya sampai suatu taraf yang dianggap manusiawi (Bappenas, 2004). Dimensi utama kemiskinan adalah politik, sosial budaya, dan psikologi, ekonomi dan akses terhadap asset. Dimensi tersebut saling terkait dan saling mengunci atau membatasi. Kemiskinan adalah kelaparan, tidak memiliki tempat tinggal, bila sakit tidak memiliki biaya untuk berobat. Orang miskin pada umumnya tidak dapat membaca karena tidak mampu bersekolah, tidak memiliki pekerjaan, takut menghadapi masa depan, kehilangan anak karena sakit akibat kekurangan air bersih, kemiskinan adalah ketidakberdayaan, terpinggirkan dan tidak memiliki rasa bebas.

\section{Penanggulangan Kemiskinan}

Kemiskinan merupakan salah satu
masalah utama dalam persoalan
pembangunan. Teori ekonomi mengatakan
bahwa untuk memutuskan mata rantai
lingkaran kemiskinan dapat dilakukan
dengan meningkatkan keterampilan
sumberdaya manusianya, penambahan
modal investasi dan mengembangkan

teknologi melalui berbagai suntikan pendanaan, sehingga diharapkan dapat meningkatkan produktivitas.

Menurut Suharto (2003), untuk mengatasi kemiskinan diperlukan sebuah kajian yang lengkap sebagai acuan perancangan kebijakan dan program anti kemiskinan, dan hampir semua pendekatan yang mengkaji masalah kemiskinan bersandar pada teori-teori pertumbuhan ekonomi neo klasik dan model yang berpusat pada produksi.

Pembangunan sering kali dianggap sebagai suatu obat terhadap berbagai masalah yang muncul dalam masyarakat, khususnya pada negara yang sedang berkembang. Permulaan implementasi pendekatan pembangunan ketika dikemukakannya teori pertumbuhan oleh kelompok ekonom ortodok. Teori ini menjelaskan bahwa pembangunan sebagai pertumbuhan ekonomi akhirnya diasumsikan akan meningkatkan standar kehidupan. Penggunaan GNP sebagai salah satu indikator keberhasilan pembangunan, tetapi jika diperhatikan lebih jauh ternyata pertumbuhan yang ada hampir tidak bermakna bagi masyarakat yang berada dibawah garis kemiskinan, karena GNP tidak diikuti dengan peningkatan kesejahteraan masyarakat. Ada beberapa pendekatan pembangunan, antara lain: pendekatan pertumbuhan, pertumbuhan dan pemerataan, ketergantungan, tata ekonomi baru, kebutuhan pokok.

Menurut Rostow (1980), dalam teori pendekatan pembangunan yang menggambarkan tahapan dalam pembangunan yang pada intinya terkait investasi "modal besar" atau mengenai "suntikan investasi yang padat modal untuk mendongkrak sumberdaya dan potensi yang ada pada masyarakat". Pendekatan yang dianggap mujarab untuk negara-negara kaya di utara ini dicangkokkan dan diterapkan guna mengobati negara-negara selatan. Dalam penerapannya, strategi untuk melakukan pembangunan dilakukan dengan memperhatikan laju pertumbuhan ekonomi 
yang dikehendaki sebagai indikator utamanya. Dengan menggunakan teori tersebut, sebagai negara dunia ketiga mengerahkan para teknokrat dan pakarnya untuk melaksanakan "strategi pembangunan" yang dirancang dengan sasaran tunggal yaitu bagaimana untuk mencapai tingkat pertumbuhan ekonomi yang tinggi dalam waktu yang singkat. Untuk memenuhi hal tersebut, sangat diperlukan modal investasi dalam jumlah yang besar, yang tentunya tidak dimiliki oleh negara-negara dunia ketiga, dan sebagai jalan pintas dibukalah pintu lebarlebar untuk investasi modal asing beserta teknologi untuk masuk ke negara tersebut.

Pembangunan dalam kerangka otonomi daerah harus berdasarkan teori/ konsep yang sesuai dengan perkembangan dan kemajuan pembangunan. Terdapat teori-teori yang masih relevan untuk diterapkan sebagai suatu pola dalam mengembangkan pembangunan. Konsep pembangunan menurut Malthus tidak menganggap proses pembangunan ekonomi terjadi dengan sendirinya, malahan proses pembangunan ekonomi memerlukan berbagai usaha yang konsisten dipihak rakyat. Proses tersebut memberikan gambaran adanya gerakan menuju keadaan stasioner tetapi menekankan bahwa perekonomian mengalami kemerosotan beberapa kali sebelum mencapai tingkat tertinggi dari pembangunan. Jadi menurut Malthus proses pembangunan adalah suatu proses naik turunnya aktivitas ekonomi lebih daripada sekedar lancar atau tidaknya aktivitas ekonomi (Saharia, 2003).

Teori ini menitikberatkan perhatian pada perkembangan kesejahteraan suatu negara, yaitu pembangunan ekonomi yang dapat dicapai dengan meningkatkan kesejahteraan suatu negara sebagian tergantung pada kuantitas produk yang dihasilkan oleh tenaga kerjanya, dan sebagian lagi pada nilai atas produk tersebut. Pembangunan dan tujuannya memiliki pengertian ataupun persepsi baik secara individual maupun sebagai kelompok yang tentu menaruh harapan yang besar pada pembangunan, bahwa keadaan masyarakat akan menjadi lebih baik melalui pembangunan. Pembangunan sering menjadi perdebatan akademik dan perdebatan ideologi. Negara yang semula dibawah penjajahan kolonial, setelah merdeka hanya melihat pembangunan sebagai salah satu cara untuk survive dan sekaligus untuk mengejar ketertinggalan. Rusli (2004) memberi arti pembangunan ekonomi dengan membedakan antara pertumbuhan (growth) dan perkembangan (development) dimana pertumbuhan dan perkembangan terjadi bersama-sama, tetapi pertumbuhan dapat terjadi tanpa perkembangan.

Pembangunan ekonomi perdesaan merupakan satu kesatuan antara sektor pertanian dan industri. Pengembangan agroindustri ini, sekaligus dapat menyediakan lapangan pekerjaan bagi masyarakat desa yang sejalan dengan berkembangnya kegiatan di dalam sektor pertanian (on-farm) dan di luar pertanian (off-farm) melalui proses pengolahan serta kegiatan jasa perdagangan komoditas primer. Berkembangnya kegiatan tersebut akan meningkatkan nilai tambah, diversifikasi produksi perdesaan, pendapatan petani, serta mempercepat akumulasi kapital perdesaan (Sandra, 2002). Menurut Kurniawati (2002), program yang perlu dikembangkan di perdesaan untuk sektor pertanian dan industri kecil adalah komoditas yang berpotensi meningkatkan nilai tambah produk pertanian, pengembangan sistem pemasaran yang tidak terdistorsi, penyediaan sarana transportasi dan distribusi produk, serta pengembangan kemitraan dan restrukturisasi sistem kelembagaan pertanian dan agroindustri.

Alternatif lain penanggulangan kemiskinan adalah dengan pengembangan masyarakat, dimana proses ini tidak terlepas dari pengertian pembentukan modal manusia. Pembentukan modal manusia adalah proses memperoleh dan meningkatkan jumlah orang yang 
mempunyai keahlian, pendidikan dan pengalaman yang akhirnya akan menentukan pembangunan ekonomi dan politik suatu negara. Meskipun arah pembangunan pertanian adalah untuk meningkatkan kesejahteraan masyarakat petani. Namun, seringkali kronologi yang diterapkan tidak netral terhadap initial endowment petani, maka tidak semua petani dapat langsung memanfaatkan atau terlibat dalam program-program pembangunan pertanian. Untuk mengatasi hal tersebut, program pembangunan pertanian yang langsung terkait dengan penanggulangan kemiskinan yang perlu diimplementasikan adalah berupa pembagian benih atau bibit tanaman dan hewan bagi pengembangan di daerahdaerah yang memerlukan perhatian khusus seperti daerah lahan kering marjinal, daerah transmigrasi dan daerah pantai (Kasryno dan Suryana, 1987).

\section{Kelembagaan Masyarakat dalam Penanggulangan Kemiskinan}

Pengembangan masyarakat tidak terlepas dari pengertian pembentukan modal manusia. Saharia (2003) menyatakan bahwa pembentukan modal manusia adalah proses memperoleh dan meningkatkan jumlah orang yang mempunyai keahlian, pendidikan dan pengalaman yang menentukan bagi pembangunan ekonomi dan politik suatu negara. Pembentukan modal manusia karenanya dikaitkan dengan investasi pada manusia tersebut dan pengembangan menuju ke arah yang kreatif dan produktif.

Saharia (2003), menyatakan terdapat lima cara pengembangan sumberdaya manusia, antara lain dengan memberikan: 1) Fasilitas dan pelayanan kesehatan, pada umumnya mencakup semua pengeluaran yang mempengaruhi harapan hidup, kekuatan dan stamina, tenaga serta vitalitas rakyat; 2) Latihan jabatan, termasuk jenis pelatihan pengembangan SDM yang diorganisasikan oleh perusahaan; 3) Pendidikan yang diorganisasikan secara formal pada tingkat dasar, menengah dan tinggi; 4) Pelatihan bagi orang dewasa yang tidak diorganisasikan oleh perusahaan, termasuk program penyuluhan khususnya pada pertanian; 5) Rotasi jabatan kepemimpinan perorangan dan keluarga untuk menyesuaikan diri dengan kesempatan kerja yang selalu berubah.

Sumardjo (2004), menyatakan bahwa seseorang akan berpartisipasi dalam masyarakat apabila terpenuhi prasyarat untuk berpartisipasi sebagai berikut: 1) Kesempatan, yaitu adanya suasana atau kondisi lingkungan yang disadari oleh orang tersebut bahwa seseorang berpeluang untuk berpartisipasi; 2) Kemauan, adanya suatu yang menumbuhkan minat dan sikap mereka untuk termotivasi berpartisipasi, misalnya berupa manfaat yang dapat dirasakan atas partisipasinya tersebut; dan 3) Kemampuan, adanya kesadaran dan keyakinan pada dirinya bahwa ia mempunyai kemampuan untuk berpartisipasi, dapat berupa pikiran, tenaga, waktu atau sarana dan material lainnya. Apabila salah satu saja dari ketiga prasyarat di atas itu tidak dapat dilaksanakan maka partisipasi yang sebenarnya dalam pembangunan tidak akan pernah terjadi.

\section{Strategi Penanggulangan Kemiskinan}

Hakikat pembangunan pertanian diarahkan untuk meningkatkan kesejahteraan masyarakat petani. Namun, seringkali kronologi yang diterapkan tidak netral terhadap initial endowment petani, maka tidak semua petani dapat langsung memanfaatkan atau terlibat dalam program-program pembangunan pertanian. Untuk mengatasi hal tersebut, program pembangunan pertanian yang langsung terkait dengan penanggulangan kemiskinan yang perlu diimplementasikan adalah berupa pembagian benih atau bibit tanaman dan hewan bagi pengembangan di daerah-daerah yang memerlukan perhatian 
khusus seperti daerah lahan kering marjinal, daerah transmigrasi dan daerah pantai (Kasryno dan Suryana, 1987).

Badan Pusat Statistik (2004), menjelaskan bahwa ada beberapa strategi yang dapat dilakukan dalam menanggulangi masalah kemiskinan, diantaranya adalah melalui kebijakan makro ekonomi, pendekatan kewilayahan, dan pendekatan pemenuhan hak-hak dasar kebutuhan manusia. Kebijakan makro ekonomi untuk menanggulangi kemiskinan adalah dengan cara meningkatkan pertumbuhan ekonomi, stabilitas ekonomi dan penciptaan lapangan kerja. Pendekatan kewilayahan yang digunakan untuk menanggulangi kemiskinan adalah dengan percepatan pembangunan perdesaan, pembangunan perkotaan, pengembangan kawasan pesisir, dan percepatan pembangunan di daerah tertinggal. Strategi penanngulangan kemiskinan yang dilakukan melalui pendekatan pemenuhan hak-hak dasar adalah dengan melakukan pemenuhan hak atas pangan, sandang, pendidikan, kesehatan, akses terhadap sumberdaya sosial dan ekonomi, kegiatan usaha produktif, perumahan air bersih dan rasa aman.

Menurut Saharia (2003), paradigma baru dalam penanggulangan kemiskinan yaitu melakukan pembangunan perdesaan, dimana pertanian diposisikan sebagai sumber pendapatan yang menjanjikan dan hasil yang memadai. Pertanian dapat menjadi sumber pendapatan yang memadai apabila setiap program melibatkan partisipasi aktif masyarakat yang ada di wilayah perdesaan (sekitar 75\%) dari total penduduk dan tentunya disesuaikan dengan potensi yang dimiliki dalam hal ini potensi sumberdaya manusianya dan potensi sumberdaya alamnya.

\section{Paradigma Pembangunan Pertanian}

Paradigma pembangunan pertanian dapat dicapai apabila potensi sumberdaya manusia di perdesaan, yang sebelumnya menjadi objek, diposisikan menjadi subjek pada setiap kegiatan yang akan dilaksanakan di sektor pertanian. Wahab (2004) menyatakan bahwa kemiskinan petani disebabkan oleh beberapa permasalahan pokok seperti: 1) Pendidikan petani yang rendah; 2) Terbatasnya akses terhadap petani; 3) Letak lahan pertanian yang dikelola tersebar di berbagai tempat dengan luasan masing-masing yang sempit dan pengelolaannya belum mengarah pada usaha intensif; 4) Lemah dan rendahnya teknologi, produktivitas, tenaga kerja, SDM dan modal; 5) Kelembagaan sosial dan ekonomi di tingkat petani belum mampu mendukung kegiatan usahatani, distribusi dan pemasaran serta informasi dan ahli teknologi; dan 6) Harga jual hasil produksi berfluktuasi. Selanjutnya Kurniawati (2002) menjelaskan bahwa program yang perlu dikembangkan di perdesaan untuk membangun dan mengembangkan sektor pertanian dan industri kecil salah satunya adalah dengan mengembangkan komoditas unggulan.

\section{Kerangka Pemikiran}

Kemiskinan merupakan penyakit ekonomi pada suatu daerah yang harus di tanggulangi. Kemiskinan menyebabkan ketidakberdayaan masyarakat dalam mengelola sumberdaya alam, sumberdaya manusia, dan modal. Kemiskinan banyak terjadi di wilayah perdesaan yang identik dengan wilayah pertanian. Petani yang memiliki lahan cukup besar akan berpeluang memiliki pendapatan lebih tinggi jika dibandingkan dengan petani yang memiliki lahan lebih kecil.

Memahami kemiskinan di Kabupaten Bogor dapat dilakukan dengan memahami permasalahan kemiskinan yang berkaitan dengan karakteristik masyarakat miskin, kemampuan daya beli masyarakat dan perlu juga mengetahui hubungan antara tingkat kemiskinan dengan beberapa karakteristik masyarakat di Kabupaten Bogor. Dengan potensi pertanian yang cukup besar, Kabupaten Bogor harus 
menjadi sektor basis dalam penanggulangan kemiskinan. Dari berbagai potensi yang ada, maka ubi jalar, padi sawah, jeruk siam dan manggis dapat menjadi komoditas unggulan yang dapat dimanfaatkan untuk penanggulangan kemiskinan.

Beberapa upaya penangggulangan kemiskinan yang telah dilakukan oleh pemerintah Kabupaten Bogor dalam bentuk program bantuan seperti PUAP, JPS, dan PNPM belum dapat dianggap berhasil sehingga perlu dilakukan evaluasi untuk melihat tingkat keberhasilan, efektivitas dan ketepatan sasaran. Dengan belum optimalnya program yang dilakukan oleh pemerintah, maka diperlukan sebuah rancangan program alternatif dan strategi penanggulangan kemiskinan yang berbasis pada pertanian sesuai dengan potensi yang dimiliki Kabupaten Bogor guna mencapai kesejahteraan pada masyarakat. Seperti terlihat pada Gambar 1.

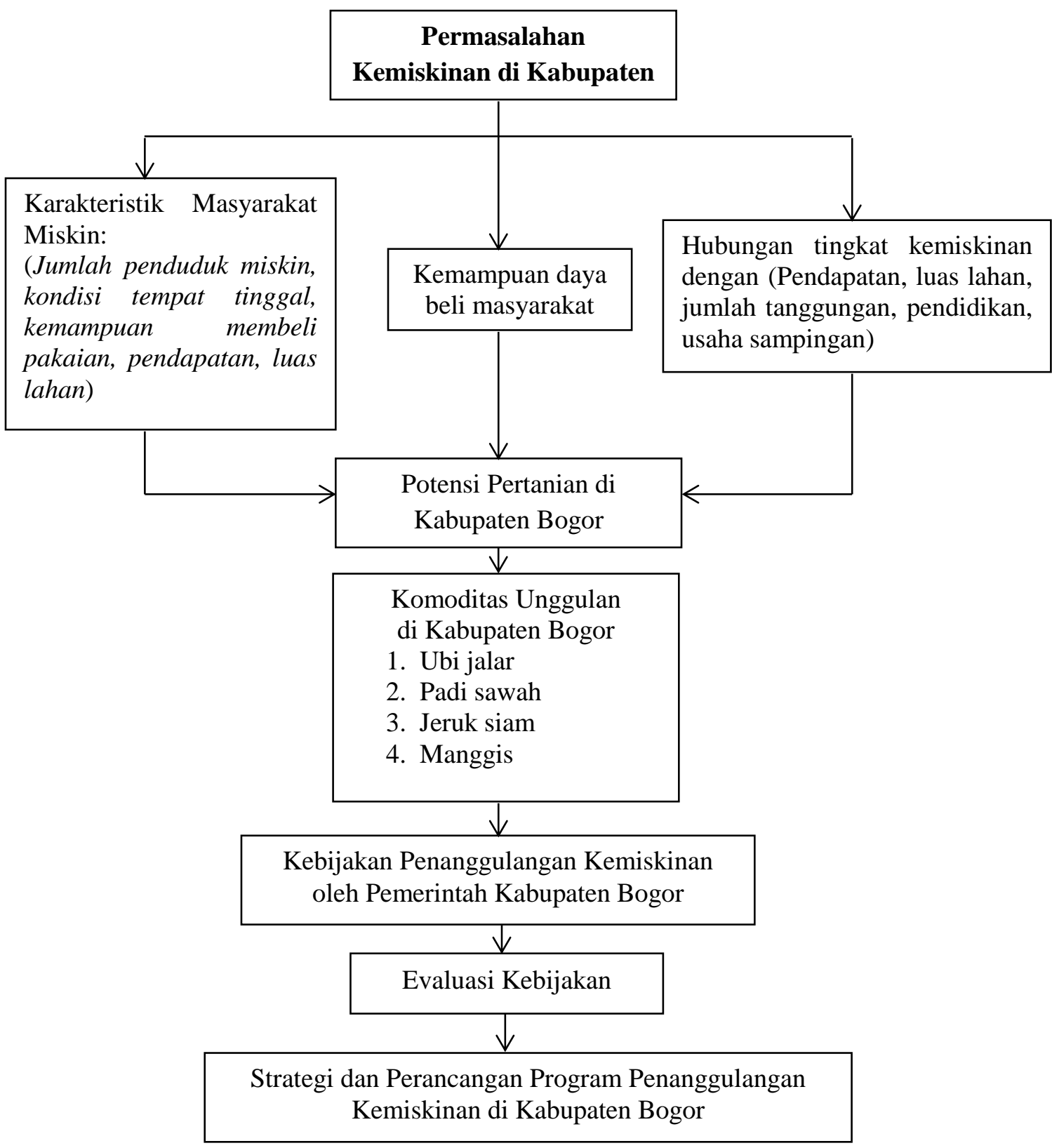

Gambar. 1 Kerangka Pemikiran Kajian 


\section{METODE PENELITIAN}

\section{Lokasi dan Waktu Penelitian}

Kajian dilaksanakan di Kabupaten Bogor bagian barat, tepatnya di wilayah zona II pengembangan pertanian dan perdesaan dengan daerah sampel Kecamatan Pamijahan dan Kecamatan Leuwiliang. Kedua kecamatan ini diambil sebagai daerah sampel dengan pertimbangan: 1) Kedua Kecamatan ini terletak pada zona yang sama dengan basis pertanian sebagai mata pencaharian utama; 2) Kecamatan Pamijahan memiliki jumlah penduduk miskin terbesar di Kabupaten Bogor; 3) Kecamatan Leuwiliang memiliki tingkat kemiskinan yang tinggi; 4) Ciri-ciri rumahtangga miskin pada dua kecamatan tersebut hampir homogen; dan 5) Dua kecamatan ini sebagian besar penduduknya bermata pencaharian utama pada sektor pertanian. Waktu pelaksanaan kajian ini selama tiga bulan yaitu dari bulan JanuariMaret 2010.

\section{Jenis dan Sumber Data}

Sumber data yang digunakan dalam penelitian ini berupa data sekunder dan data primer. Data sekunder berupa jumlah penduduk miskin, luas lahan, pendidikan, jumlah tanggungan, usaha sampingan dan kepemilikan pakaian diperoleh dari data SUSDA 2006, BAPPEDA Kabupaten Bogor, PSP3 IPB, BPS Kabupaten Bogor, Kantor BP3K wilayah Kecamatan Pamijahan dan Leuwiliang. Sementara data primer yang berupa komoditas unggulan, evaluasi program penanggulangan kemiskinan dan perumusan strategi penanggulangan kemiskinan di Kabupaten Bogor diperoleh dari hasil survei, wawancara, focus group discussion (FGD) dengan para petani, penyuluh pertanian dan kepala BP3K masing-masing kecamatan. Lebih legkapnya untuk jenis dan sumber data serta metode analisis dapat dilihat pada Tabel 2.

\section{Metode Analisis}

Metode pengolahan dan analisis yang digunakan pada penelitian terdiri dari:

1. Analisis deskripsi kuantitatif yang digunakan untuk mengidentifikasi karakteristik dan kemampuan daya beli masyarakat miskin di Kabupaten Bogor.

2. Analisis korelasi, digunakan untuk menguji adanya hubungan antara tingkat kemiskinan dengan beberapa karakteristik rumah tangga miskin di Kabupaten Bogor. Korelasi yang digunakan adalah korelasi Spearman.

3. Analisis Location Quotient (LQ), digunakan untuk menunjukkan lokasi pemusatan atau basis aktivitas dan mengetahui kapasitas ekspor perekonomian wilayah serta tingkat kecukupan barang atau jasa dari produksi lokal suatu wilayah.

\section{Analisis Strength Weakness Opportunity Threat (SWOT),} dilakukan menggunakan unit analisis berupa wilayah untuk basis penelitian, yaitu berupa dua kecamatan yang terdapat di Kabupaten Bogor bagian barat: Pamijahan dan Leuwiliang.

Metode Perumusan Strategi dan Perancangan Program, dilakukan dengan menggunakan Quantitative Strategic Planning Matrix (QSPM). Analisis QSPM juga digunakan pada tahap pengambilan keputusan karena menunjukkan strategi alternatif yang paling baik dipilih. 
Tabel. 2. Data dan Metoda Analisis

\begin{tabular}{|c|c|c|c|c|}
\hline \multirow{2}{*}{\multicolumn{2}{|c|}{ Tujuan Kajian }} & \multicolumn{2}{|c|}{ Data } & \multirow{2}{*}{ Metode Analisis } \\
\hline & & Jenis & Sumber & \\
\hline 1 & $\begin{array}{l}\text { Mengidentifikasi karakteristik } \\
\text { dan kemampuan Daya Beli } \\
\text { masyarakat miskin di } \\
\text { Kabupaten Bogor }\end{array}$ & $\begin{array}{l}\text { Sekunder: Jumlah } \\
\text { penduduk miskin tiap } \\
\text { kecamatan, Kondisi } \\
\text { dan keadaan tempat } \\
\text { tinggal, Kepemilikan } \\
\text { aset dan Tingkat } \\
\text { pendidikan }\end{array}$ & $\begin{array}{l}\text { SUSDA 2006, } \\
\text { BAPPEDA } \\
\text { PSP3 IPB }\end{array}$ & $\begin{array}{l}\text { Deskriptif } \\
\text { Kuantitatif }\end{array}$ \\
\hline 2 & $\begin{array}{l}\text { Menganalisis hubungan antara } \\
\text { tingkat kemiskinan dengan } \\
\text { beberapa karakteristik RTM } \\
\text { di Kabupaten Bogor }\end{array}$ & $\begin{array}{l}\text { Sekunder: Tingkat } \\
\text { kemiskinan, } \\
\text { Pengeluaran rumah } \\
\text { tangga, Status } \\
\text { kepemilikan lahan, } \\
\text { Jumlah tanggungan, } \\
\text { Tingkat pendidikan, } \\
\text { Usaha sampingan }\end{array}$ & $\begin{array}{l}\text { BAPPEDA, PSP3 } \\
\text { IPB, Bogor Dalam } \\
\text { Angka } 2007\end{array}$ & Korelasi \\
\hline 3 & $\begin{array}{l}\text { Menganalisis komoditas } \\
\text { pertanian unggulan di } \\
\text { Kabupaten Bogor untuk } \\
\text { penanggulangan kemiskinan }\end{array}$ & $\begin{array}{l}\text { Sekunder: Jenis } \\
\text { Komoditas Pertanian } \\
\text { Unggulan di } \\
\text { Kabupaten Bogor }\end{array}$ & $\begin{array}{l}\text { Dinas Pertanian } \\
\text { dan Kehutanan } \\
\text { Kabupaten Bogor, } \\
\text { BAPPEDA dan } \\
\text { PSP3 IPB }\end{array}$ & LQ \\
\hline 4 & $\begin{array}{l}\text { Mengevaluasi Kebijakan } \\
\text { Pemerintah mengenai } \\
\text { Program penanggulangan } \\
\text { Kemiskinan }\end{array}$ & $\begin{array}{l}\text { Sekunder: Program } \\
\text { Pemerintah dalam } \\
\text { Penanggulangan } \\
\text { Kemiskinan }\end{array}$ & $\begin{array}{l}\text { BAPPEDA, BP3K } \\
\text { Wilayah Pamijahan } \\
\text { dan Leuwiliang }\end{array}$ & $\begin{array}{l}\text { FGD, } \\
\text { Deskriptif } \\
\text { Kuatitatif }\end{array}$ \\
\hline 5 & $\begin{array}{l}\text { Merumuskan strategi dan } \\
\text { program penanggulangan } \\
\text { kemiskinan melalui } \\
\text { pengembangan komoditas } \\
\text { pertanian unggulan di } \\
\text { Kabupaten Bogor }\end{array}$ & Primer & Survei & $\begin{array}{l}\text { Analisis SWOT } \\
\text { Analisis QSPM }\end{array}$ \\
\hline
\end{tabular}

\section{HASIL DAN PEMBAHASAN}

\section{Karakteristik dan Kemampuan Daya Beli Masyarakat Miskin di Kabupaten Bogor}

\section{Data Bappeda Kabupaten Bogor} (2008) menunjukkan bahwa jumlah penduduk miskin di Kabupaten Bogor mencapai 1.149.508 jiwa. Jumlah penduduk miskin di Kecamatan Pamijahan 47,94 persen dari 134.865 penduduk, dan di Kecamatan Leuwiliang sebesar 48,99 persen dari 111.705 penduduk.
Berdasarkan kondisi tempat tinggal, karakteristik kemiskinan terlihat pada masih dominannya jenis dinding rumah yang berasal dari bambu (lebih dari 60\%).

Berdasarkan kepemilikan WC, terlihat karakteristik kemiskinan masyarakat di Kecamatan Pamijahan dan Leuwiliang yaitu lebih dari 57 persen masyarakat masih membuang kotoran di sungai dan kurang dari 1 persen masyarakat yang memiliki WC sendiri. Berdasarkan kemampuan membeli pakaian per tahun, karakteristik kemiskinan di Kecamatan Pamijahan dan Leuwiliang terlihat pada masih banyaknya masyarakat 
yang tidak mampu membeli pakaian per tahun (50,27\% di Pamijahan dan 71,20\% di Leuwiliang). Berdasarkan tingkat pendidikan kepala keluarga, karakteristik kemiskinan terlihat pada masih banyaknya kepala keluarga yang tidak tamat SD (50\% di Kecamatan Leuwiliang dan 60\% di Kecamatan Pamijahan). Sementara karakteristik kemiskinan lain dapat dilihat dari semakin meningkatnya jumlah RTM penerima Raskin di Kabupaten Bogor, yaitu dari 151.113 RTM (2007) menjadi 256.881 RTM (2008).

Kemampuan daya beli masyarakat di Kabupaten Bogor masih tergolong rendah. Kemampuan daya beli ini salah satunya dipengaruhi oleh rendahnya pendapatan masyarakat di Kabupaten Bogor. Pendapatan masyarakat di Kabupaten Bogor khususnya di Kecamatan Pamijahan dan Leuwiliang masih berada pada kisaran $\mathrm{Rp} 475.026$ untuk di perdesaan dan Rp 576.209 untuk di perkotaan. Besarnya pendapatan tersebut masih berada di bawah standar BPS yaitu Rp 600.000 per bulan. Berdasarkan kemampuan daya beli antara masyarakat perdesaan dengan perkotaan di Kabupaten Bogor terlihat bahwa secara umum tingkat daya beli masyarakat perkotaan lebih tinggi dari tingkat daya beli masyarakat perdesaan. Hal ini menunjukkan bahwa kemiskinan banyak terjadi pada masyarakat perdesaan.

\section{Hubungan Tingkat Kemiskinan dengan Karakteristik RTM di Kabupaten Bogor}

Tingkat kemiskinan di Kabupaten Bogor dari tahun ke tahun cenderung meningkat, yaitu sebanyak 453.400 jiwa pada 2003 menjadi 1.149 .508 jiwa pada 2008. Terjadinya peningkatan jumlah penduduk miskin karena meningkatnya jumlah pengangguran, yaitu dari 194.902 jiwa (2004) menjadi 598.032 jiwa (2008). Peningkatan ini terjadi karena kurangnya jumlah lapangan kerja dan meningkatnya jumlah angkatan kerja tiap tahun.
Dari hasil analisis korelasi, di Kecamatan Pamijahan terdapat tingkat signifikansi yang kuat antara kemiskinan dengan pendapatan $(-0,629)$, luas lahan (0,612), jumlah tanggungan keluarga $(0,533)$ dan jumlah kepala keluarga yang tidak tamat SD $(0,663)$, namun terdapat tingkat signifikansi yang lemah antara kemiskinan dengan usaha sampingan (0,278 ) yang dimiliki oleh masyarakat.

Sementara hasil analisis korelasi di Kecamatan Leuwiliang terdapat tingkat signifikansi yang kuat antara tingkat kemiskinan dengan pendapatan masyarakat $(-0,569)$ dan usaha sampingan $(-0,579)$. Hal ini disebabkan sumber pendapatan masyarakat di Kecamatan Leuwiliang tidak hanya bergantung pada sektor pertanian dan banyak masyarakat petani yang memiliki usaha sampingan. Terdapat korelasi yang signifikan lemah antara kemiskinan dengan luas lahan $(-0,355)$, jumlah tanggungan $(0,497)$ dan jumlah kepala keluarga yang tidak tamat SD $(0,029)$. Hal ini terjadi karena tidak banyak luas lahan yang dimiliki oleh petani, jumlah tanggungan dikalangan masyarakat yang besarnya hampir merata dan tingkat pendidikan sangat rendah yang dimiliki oleh sebagian besar kepala keluarga di Kecamatan Leuwiliang.

\section{Komoditas Unggulan di Kabupaten Bogor}

Berdasarkan pada hasil analisis LQ terhadap komoditas pertanian yang terdapat di Kabupaten Bogor, maka komoditas ubi jalar, padi sawah, jeruk siam dan manggis merupakan komoditas unggulan di Kecamatan Pamijahan dan Leuwiliang. Nilai LQ ubi jalar sebesar 2,24, nilai LQ padi sawah sebesar 1,17 dan 1,09, nilai LQ jeruk siam sebesar 5,56 dan nilai LQ manggis sebesar 8,03.

Dengan nilai LQ tertinggi, manggis memang menjadi komoditas unggulan yang terdapat di Kabupaten Bogor, namun dalam kenyataan di lapangan tanaman ini mengalami kegagalan disebabkan oleh 
penebangan pohon yang dilakukan oleh masyarakat sehingga manggis perlu dibudidayakan kembali. Pengembangan komoditas unggulan berupa ubi jalar terdapat di Kecamatan Pamijahan tepatnya terletak di Desa Gunung Bunder 1 dan 2 dengan produksi terbesar sebanyak 600 ton, produksi padi sawah terbesar terdapat di Desa Ciasihan sebesar 6.000 ton, produksi jeruk siam terbesar terdapat di Desa Gunung Picung, Cibitung Kulon dan Cibitung Wetan sebanyak 10 kwintal. Sementara itu, pengembangan komoditas unggulan padi sawah di Kecamatan Leuwiliang yaitu di Desa Pabangbon, Barengkok dan Karyasari dengan produksi terbesar masingmasing 2.501 ton, 1.255 ton, dan 1.192 ton. Produksi manggis terbesar di Kecamatan Leuwiliang yaitu di Desa Karyasari dengan nama manggis "Bogor Raya" (Dinas Pertanian dan Kehutanan Kabupaten Bogor, 2008; BPS, 2008).

Dari hasil penelitian ini terlihat bahwa Kabupaten Bogor, khususnya Kecamatan Pamijahan dan Leuwiliang merupakan sentra pertanian yang memiliki lebih dari satu komoditas unggulan yang dapat dikembangkan sebagai basis perekonomian masyarakat.

\section{Evaluasi Program Penanggulangan Kemiskinan}

Ismawan (2002) menyatakan bahwa dalam menanggulangi kemiskinan pada masyarakat diperlukan upaya-upaya khusus dalam memberdayakan masyarakat melalui program peningkatan SDM, teknologi, kelembagaan maupun permodalan. Berdasarkan hasil wawancara, terdapat program-program penanggulangan kemiskinan yang dilakukan oleh pemerintah untuk masyarakat terutama bagi para petani, diantaranya Raskin, Bantuan Langsung Tunai (BLT), Program Usaha Agribisnis Perdesaan (PUAP), Gerakan Masyarakat Mandiri (GMM),
(LUEP), Program Ketahanan Pangan (PKP) dan KUBE.

Namun demikian, hasil FGD dengan 10 orang perwakilan masyarakat dari Kecamatan Pamijahan dan Kecamatan Leuwiliang menunjukkan bahwa telah terjadi beberapa kekeliruan pada penanggulangan kemiskinan yang dilakukan oleh pemerintah, diantaranya kekeliruan dalam hal ketepatan sasaran, kekeliruan dalam hal program yang dijalankan lebih bernuansa karitatif (kemurahan hati) ketimbang produktivitas, kekeliruan memosisikan masyarakat miskin sebagai objek daripada subjek, kekeliruan Pemerintah masih bertindak sebagai penguasa daripada sebagai fasilitator, serta kekeliruan masih berorientasinya program pada aspek ekonomi daripada aspek multidimensional.

Mencermati beberapa kekeliruan tersebut, maka terdapat beberapa langkah evaluasi untuk memperbaiki kekeliruan dan yang harus dilakukan, antara lain: 1) Diperlukan suatu strategi pendataan yang baik agar dapat diketahui data jumlah penduduk miskin yang tepat sehingga program penanggulangan kemiskinan dapat tepat sasaran; 2) Dilakukan peningkatan kemampuan dasar masyarakat miskin untuk meningkatkan pendapatan melalui langkah perbaikan pendidikan dan kesehatan, peningkatan keterampilan usaha, teknologi, perluasan jaringan kerja, serta informasi pasar; 3) Melibatkan masyarakat miskin dalam keseluruhan proses penanggulangan kemiskinan mulai dari proses perencanaan, pelaksanaan, pengawasan, dan evaluasi, bahkan pada proses pengambilan keputusan; 4) Strategi pemberdayaan; 5) Strategi pengentasan kemiskinan tepatnya diarahkan untuk mengikis nilai-nilai budaya negatif (apatis, apolitis, fatalistik, ketidakberdayaan, dan sebagainya).

Selanjutnya, evaluasi program penanggulangan kemiskinan minimal dilakukan dari tiga segi, yaitu segi sifat (program penanggulangan kemiskinan di Kabupaten Bogor masih bersifat karitatif), 
segi pendekatan (program penanggulangan kemiskinan di Kabupaten Bogor masih terfokus pada aspek ekonomi), dan segi sasaran (program penanggulangan kemiskinan yang dilakukan belum berhasil). Untuk itu, hasil kajian Bappeda Kabupaten Bogor (2007) menyatakan bahwa upaya penggulangan kemiskinan harus menganut pada prinsip-prinsip seperti keberpihakan, partisipatif, berwawasan gender, keberlanjutan, pemberdayaan, produktivitas, kebersamaan, keterbukaan, akuntabilitas, dan sinergitas.

\section{Perumusan Strategi dan Perancangan Program Penanggulangan Kemiskinan}

$\begin{array}{rlrr}\text { Analisis } & \text { SWOT yang } & \text { dilakukan } \\ \text { menghasilkan } & 9 \quad \text { rumusan } & \text { strategi }\end{array}$

penanggulangan kemiskinan yang dapat digunakan oleh pemerintah daerah Kabupaten Bogor. Secara umum strategi alternatif tersebut dapat dilihat pada Tabel 3. Dari hasil analisis QSPM, strategi peningkatan kualitas SDM petani mendapatkan nilai kemenarikan (attractive score) yang tertinggi $(7,739)$, diikuti oleh pengembangan komoditas unggulan $(7,654)$, peningkatan sarana dan prasarana pertanian (7,632), membuat kebijakan sistem anggaran pemerintah yang berpihak kepada petani $(7,582)$, sosialisasi program pemerintah secara intensif $(7,479)$, pengembangan potensi lahan pertanian dan usaha ekonomi petani $(7,398)$, peningkatan kualitas pendampingan kepada kelompok tani (7,211), membuat kebijakan sistem tata ruang yang berpihak kepada petani $(7,039)$, dan peningkatan kemitraan dengan dunia usaha $(6,884)$.

Tabel. 3 Matrik SWOT Perumusan Strategi Penanggulangan Kemiskinan di Kabupaten Bogor

\begin{tabular}{|c|c|c|}
\hline Faktoe Eksternal & $\begin{array}{l}\text { Kekuatan (Strengths) } \\
\mathrm{S} 1: \text { Lahan Pertanian yang masih } \\
\\
\text { cukup luas } \\
\mathrm{S} 2: \begin{array}{l}\text { Adanya Kelompok tani } \\
\text { sampai ke desa }\end{array} \\
\mathrm{S} 3: \begin{array}{l}\text { Terdapatnya Komoditas } \\
\text { ungggulan }\end{array} \\
\mathrm{S} 4: \begin{array}{l}\text { Adanya program } \\
\text { pemberdayaan ekonomi }\end{array}\end{array}$ & $\begin{array}{l}\text { Kelemahan (Weaknesses) } \\
\text { W1 : Terbatasnya Modal } \\
\text { W2 : Rendahnya kualitas SDM petani } \\
\text { W3 : Terbatasnya aparatur } \\
\text { pemerintah } \\
\text { W4 : Minimnya sarana dan prasarana } \\
\text { pertanian. }\end{array}$ \\
\hline $\begin{aligned} & \text { Peluang (Opportunities) } \\
& \mathrm{O} 1: \begin{array}{l}\text { Adanya Komitmen } \\
\text { pemerintah daerah dalam }\end{array} \\
& \text { penanggulangan kemiskinan } \\
& \mathrm{O} 2: \text { Besarnya potens sumberdaya } \\
& \text { alam pertanian } \\
& \mathrm{O} 3: \text { Adanya Program pemerintah } \\
& \text { dalam pengentasan } \\
& \text { kemiskinan } \\
& \mathrm{O} 4: \text { Otonomi daerah } \\
&\end{aligned}$ & \begin{tabular}{ll}
\multicolumn{1}{c}{$(\mathrm{S}-\mathrm{O})$} \\
1. \\
Peningkatkan kualitas \\
pendampingan kepada \\
kelompok tani $(\mathrm{S} 1, \mathrm{~S} 2, \mathrm{O} 1, \mathrm{O} 3)$ \\
2. \\
Pengembangan potensi lahan \\
pertanian dan usaha ekonomi \\
petani $(\mathrm{S} 3, \mathrm{~S} 4, \mathrm{O} 2, \mathrm{O} 4)$
\end{tabular} & \begin{tabular}{ll}
\multicolumn{1}{c}{$(\mathrm{W}-\mathrm{O})$} \\
1. \\
Membuat kebijakan sistem \\
anggaran pemerintah yang \\
berpihak kepada petani $(\mathrm{W} 1, \mathrm{O} 1)$ \\
2. Peningkatan kualitas SDM petani \\
(W2,O3,O4) \\
3. Peningkatan sarana dan prasarana \\
pertanian $(\mathrm{W} 3, \mathrm{~W} 4, \mathrm{O} 2)$
\end{tabular} \\
\hline $\begin{array}{l}\text { Ancaman (Threats) } \\
\text { T1 : Adanya krisis ekonomi } \\
\text { T2 : Adanya alih fungsi lahan } \\
\text { T3 : Rendahnya kepercayaan } \\
\text { kepada perbankkan } \\
\text { T4 : Adanya kesalahan persepsi } \\
\quad \text { dalam memaknai bantuan } \\
\text { pemerintah. }\end{array}$ & \begin{tabular}{ll}
\multicolumn{1}{c}{$(\mathrm{S}-\mathrm{T})$} \\
1. \\
Pengembangan komoditas \\
unggulan $(\mathrm{S} 3, \mathrm{~S} 4, \mathrm{~T} 1)$
\end{tabular} & $(\mathrm{W}-\mathrm{T})$ \\
\hline
\end{tabular}




\section{KESIMPULAN DAN SARAN}

\section{Kesimpulan}

1. Karakteristik kemiskinan yang terjadi di Kecamatan Pamijahan dan Leuwiliang terlihat dari jumlah penduduk miskin yang tinggi (47$48 \%$ ), kondisi tempat tinggal yang jenis dindingnya masih dari bambu (>60\%), kepemilikan WC $(<1 \%)$, kemampuan membeli pakaian (50$70 \%$ ), dan tingkat pendidikan kepala keluarga yang rendah (50-60\% tidak tamat SD). Kemiskinan di Kecamatan Pamijahan dan Leuwiliang terlihat juga dari pendapatan masyarakat yang rendah (dibawah standar BPS yaitu Rp 600.000), kemampuan daya beli masyarakat yang rendah, jumlah keluarga penerima Raskin yang masih banyak dan keterbatasan masyarakat terhadap akses untuk memperoleh kesejahteraan masih sulit.

2. Terdapat korelasi antara tingkat kemiskinan dengan karakteristik rumahtangga miskin. Di Kecamatan Pamijahan terdapat korelasi dengan tingkat signifikansi yang kuat antara kemiskinan dengan pendapatan, luas lahan, jumlah tanggungan keluarga dan jumlah kepala keluarga yang tidak tamat SD, namun terdapat tingkat signifikansi yang lemah antara kemiskinan dengan usaha sampingan. Sedangkan di Kecamatan Leuwiliang terdapat korelasi dengan tingkat signifikansi yang kuat antara tingkat kemiskinan dengan pendapatan dan usaha sampingan, namun terdapat tingkat signifikansi yang lemah antara tingkat kemiskinan dengan luas lahan, jumlah tanggungan dan jumlah kepala keluarga yang tidak tamat SD.

3. Komoditas unggulan di Kecamatan Pamijahan dan Leuwiliang berupa ubi jalar, padi sawah, jeruk siam dan manggis yang perlu dikembangkan dan dijadikan sektor basis perekonomian masyarakat.
4. Program penanggulangan kemiskinan yang dilakukan pemerintah Kabupaten Bogor tidak optimal. Program yang dijalankan masih memiliki kekurangan dari berbagai segi. Dari segi sifat, program masih mengedepankan kemurahan hati daripada peningkatan produktivitas masyarakat miskin. Dari segi pendekatan, program masih terfokus pada aspek ekonomi ketimbang aspek multidimensi, dan dari segi sasaran, program yang dijalankan tidak tepat sasaran.

\section{Saran}

Berdasarkan hasil kajian, maka dapat disarankan bahwa penanggulangan kemiskinan di Kabupaten Bogor harus terus dilakukan oleh pemerintah dengan:

1. Meningkatan daya beli masyarakat miskin di Kabupaten Bogor dengan membuat program pengembangan ekonomi dengan mengembangkan ubi jalar, padi sawah, jeruk siam dan manggis sebagai komoditas unggulan dalam menanggulangi kemiskinan.

2. Peningkatan kualitas pendidikan masyarakat miskin melalui program penyuluhan dan pelatihan yang dilakukan oleh pemerintah Kabupaten Bogor dalam rangka menciptakan sumberdaya manusia yang berkualitas sehingga dapat bebas dari belenggu kemiskinan.

3. Kualitas infrastruktur jalan, alat pertanian dan sarana pasar yang dapat menunjang pertumbuhan ekonomi masyarakat di Kabupaten Bogor perlu di tingkatkan. 


\section{DAFTAR PUSTAKA}

[BPS] Badan Pusat Statistik. 2007. Kota Bekasi Dalam Angka 2006. Badan Pusat Statistik Kota Bekasi.

[BPS] Badan Pusat Statistik. 2004. Kriteria Keluarga Miskin di Indonesia. Badan Pusat Statistik.

Kabupaten Bogor Dalam Angka 2007. Badan Pusat Statistik Kabupaten Bogor.

[BAPPEDA] Kabupaten Bogor. 2006.

Data Sensus Daerah Kabupaten Bogor Tahun 2006.

[BAPPEDA] Kabupaten Bogor. 2007. Strategi Penanggulangan Kemiskinan Daerah Tahun 20082012.

[BAPPEDA] Kabupaten Bogor. 2008. Hasil Sensus Ekonomi Daerah Kabupaten Bogor Tahun 2007

[BAPPENAS] 2004. Laporan Perkembangan Pencapaian Pembangunan Milenium Indonesia 2004.

Dinas Pertanian dan Kehutanan Kabupaten Bogor. 2008. Monografi Pertanian dan Kehutanan 2008.

Hendrakusumaatmaja, S. 2002. Pembangunan Ekonomi Lokal dan Regional. Bogor: Institut Pertanian Bogor.

Ismawan, B. 2002. Pengalaman LSM Dalam Menanggulangi Kemiskinan. Sarasehan Nasinal "Micro Finance dan Upaya Penanggulangan Kemiskinan”. 27 Agustus 2002. Bogor: Institut Pertanian Bogor.

Kasryno, F., dan A. Suryana. 1987. Transformasi struktural Ekonomi Pedesaan Menuju Pengembangan Sentral industri Pertanian. Dalam F. Kasryno (ed). Perubahan Ekonomi Pedesaan Menuju Struktur Ekonomi Berimbang Center For Agro Economic Research. RNAM. Bangkok: ESCAP/ UNIDO

Kurniawati. 2002. Strategi Pembangunan SDM http://www.pikiranrakyat.com/ceta k/07/02/05/01.htm

Ritonga, H. 2003. Kemiskinan dan Kesenjangan Ekonomi Antar Wilayah. Makalah disampaikan pada Konsultasi Regional Produk Domistik Bruto se-Propinsi Riau, di Kepri Juli 2003.

Rostow, W.W. 1980. The Stages of Economics Growth. University of Texas Press, Austin.

Rusli, S. 2004. Pembangunan Kebutuhan Dasar Manusia, (hand out kuliah MPD). Bogor: Institut Pertanian Bogor.

Saharia, 2003. Pemberdayaan Masyarakat di Perdesaan Sebagai salah satu upaya pemanfaatan potensi sumberdaya manusia secara optimal" Makalah Individu. Pengantar Falsafah Sains (PPS702). Program Pascasarjana/S3. Institut Pertanian Bogor.

Sandra, 2002. "Memberdayakan Industri Kecil Berbasis Agroindustri di Perdesaan". Makalah Individu. Pengantar Falsafah Sains (PPS702). Program Pascasarjana/S3. Bogor: Institut Pertanian Bogor.

Sayogyo, 1987. Ekologi Pedesaan, Sebuah Bunga Rampai, Penerbit Rajawali Pers, Jakarta.

Suharto, E. 2003. Paradigma Baru studi Kemiskinan,

http://immugm.org.public.html.arti cle.php? story $=2003091119480812$ 3

Sumardjo, 2004. Pembangunan Kebutuhan Dasar Manusia, (hand out kuliah MPD) Institut Pertanian Bogor, Bogor.

Sumodiningrat, G. 1999. Pemberdayaan Masyarakat dan Jaring Pengaman Sosial. Jakarta: PT. Gramedia Pustaka Utama.

Wahab, M. S. 2004. Upaya Mengangkat Kehidupan Pekebun Kelapa: Kakao Alternatif Diversifiksi Perkebunan Rakyat. www.riaupos.com 